\title{
Incidental catch of marine organisms registered in the Chilean Antarctic krill fishery, years 2012-2016
}

\author{
Patricio M. Arana ${ }^{1}$ \& Renzo Rolleri ${ }^{1}$ \\ ${ }^{1}$ Escuela de Ciencias del Mar, Pontificia Universidad Católica de Valparaíso \\ Valparaíso, Chile \\ Corresponding author: Patricio M. Arana (patricio.arana@pucv.cl)
}

\begin{abstract}
Krill (Euphausia superba) catch is currently the most relevant fishery industry in Antarctic waters. This resource is a keystone species in the Antarctic food web, sustaining the contribution to the trophic ecology of many invertebrate and vertebrate species. To catch krill, part of the fleet in this fishery uses large mid-water nets that also retain a diversity of other organisms like plankton, meroplankton, and fish species as bycatch. Therefore, it is necessary to understand and evaluate the magnitude of this incidental catch, as well as the potential interactions between krill fishing gear with seabirds and mammals. To estimate the composition and extent of bycatch for this fishery included 784 samples of $25 \mathrm{~kg}$ and an equal number of $1 \mathrm{~kg}$ sub-samples obtained from Antarctic krill catches in Subarea 48, between years 2012 and 2016. A total of 15 fish species were identified along with the record of five other taxa and other unidentified specimens. The most relevant fish species bycaught by weight were mackerel icefish Champsocephalus gunnari, South Georgia icefish Pseudochaenichthys georgianus, and painted notie Lepidonotothen larseni. Additionally, 20 interactions with seabirds and nine interactions with Antarctic fur seals (Arctocephalus gazella) were registered. In the five years of operations, only three seabirds died, and only two individuals of A. gazelle caught by the net were killed.
\end{abstract}

Keywords: Euphausia superba; bycatch; interaction; fishes; seabirds; marine mammals; Antarctic waters

\section{INTRODUCTION}

In 2010, the Commission for the Conservation of Antarctic Marine Living Resources (CCAMLR) had implemented an information collection system in the Antarctic waters to gather information on fisheries developed in this area. This information is collected by national and international scientific observers onboard, who record biological and fishery-related data in standard formats.

The fishery for Antarctic krill (Euphausia superba) is among the oldest fishing activities in Antarctic waters and the most relevant in terms of volumes extracted (with a total catch of 390,135 $t$ in 2019). This species plays an important role in the ecosystem of this region as the prey of many other organisms, including fish, whales, penguins, flying seabirds, seals, and squids. Therefore, it is necessary to study the Antarctic krill fishery and determine the measures required for its conservation and management, also including non- target species. For example, penguins, petrels, and sea lions might be affected as bycatch when entangled in fishing gear during fishing operations. Also, the large pelagic nets used for krill fishing, using small mesh in the codend, retain other cryptic organisms like plankton.

This document analyzes the information collected by different scientific observers working onboard a Chilean flag vessel during its operation in the Antarctic krill fishery between the years 2012 and 2016. The main objective is to identify and quantify the recorded bycatch aboard this ship as well as the interactions with birds and mammals.

\section{MATERIALS AND METHODS}

This study analyzes the information collected by National Scientific Observers working onboard the FV Betanzos, a Chilean factory vessel (stern trawler, with ramp to howl the trawl over the stern, $72 \mathrm{~m}$ length and

Corresponding editor: Gustavo J. Macchi 
1,439 gross registered tonnages) during commercial fishing for Antarctic krill (Euphausia superba), carried out between 2012 and 2016.

Fishing operations were conducted in FAO Statistical Area 48, subdivided into Subareas 48.1 (West Antarctic Peninsula, Bransfield Strait, Gerlache Strait, and the South Shetland Islands), 48.2 (South Orkney Islands), and 48.3 (South Georgia Island) (Fig. 1). Krill fishing trawls were mainly carried out between 20 and $120 \mathrm{~m}$ depth, with a small number of hauls at greater depths (Arana et al., 2020).

Conventional mid-water trawling nets (Omega 200M and Gloria 192M) were used for the fishing operations, with a codend mesh size of 13-14 mm. Besides, to avoid incidental capture of penguins and marine mammals, a seal-exclusion device was installed covering the entire mouth of the net, consisting of a vertical piece of netting called "Sealnet" with mesh sizes of 12.5-15.0 cm (Davis et al., 2009; Delegation of Chile, 2015) (Fig. 2). Thus, it prevents large specimens such as flying birds, penguins, sea lions, or seals from entering the net while in the water. Additionally, there was a laser beam "Sea-Bird Saver," located on the stern, which is kept on 24 hours fixedly on the wake of the boat as a line scarecrow, at an inclination angle of approximately $45^{\circ}$.

This document analyzed information from the vessel logbooks, which include knowledge of the general characteristics of each haul (geographical location, fishing depth (m), duration of the trawl (h), and krill catch $(\mathrm{kg})$ ). Also, reports provided by the National Scientific Observers to the CCAMLR Scheme of Scientific Observation, who worked permanently onboard, were used. This information was recorded in Excel files delivered by CCAMLR to be filled in situ, according to the CCAMLR Scientific Observer Manual (CCAMLR, 2011).

A $25 \mathrm{~kg}$ sample was separated from the total catch of each examined haul to determine and quantify the presence of fish visible to the naked eye. Once analyzed, a $1 \mathrm{~kg}$ sub-sample was extracted from each sample for a more detailed analysis to determine the presence of smaller organisms other than krill. In each case, the number of specimens per species or taxa, total length $(\mathrm{mm})$, and weight per species $(\mathrm{kg})$ were recorded on the forms.

The information was analyzed by grouping all available data by year, with the records determined from the $25 \mathrm{~kg}$ samples and the $1 \mathrm{~kg}$ sub-samples. For each species or taxonomic group, the catch was calculated in the number of individuals (n) and weight $(\mathrm{kg})$ per year. Subsequently, the totals for the entire period were analyzed. These values were analyzed about the total weight of the samples examined (number of $25 \mathrm{~kg}$ samples; number of $1 \mathrm{~kg}$ subsamples) to determine the percentage of bycatch weight in the samples and the respective average number of specimens per sample and sub-sample.

Species identification was carried out to the most precise taxonomic level possible. Identification guides were used for the primary identification criteria used for fish species (Fischer \& Hureau, 1985; CCAMLR, 2013; Dongwon, 2015), fish larvae (Iwami, 1995; Iwami \& Naganobu, 2007), seabirds (CCAMLR, 1996; Onley \& Bartle, 1999) and marine mammals (Sielfeld, 1983; Fischer \& Hureau, 1985).

While trawling is done, or during the gear setting or retrieval, the seabirds and mammals' presence in the ship's vicinity occur in some hauls for about $10 \mathrm{~min}$. However, records of interactions given in this document correspond to seabirds and marine mammals that were entangled, injured or killed annually, found on the ship, either directly by the National Scientific Observer or reported by the ship's crew.

In a similar way to CCAMLR (2014, 2016, 2017), the total captured weight of each taxon/species and the frequency of occurrence (FO) were determined for each taxon/species. The FO was defined as the percent relation between the number of samples registering the presence of each species, and the total number of samples for each period. The total weight and FO were grouped into fish (Pisces), "other species" (Amphipoda, Cephalopoda, Crustacea, Pandalidae, Medusae, and Salpidae), and individuals who could not be identified were registered as "unknown species." These calculations were performed per year and for the entire period analyzed.

The total length (TL) of the specimens recorded in the samples was measured in millimeters. It was grouped into frequency distributions of $1.0 \mathrm{~cm}$ TL to achieve a better representation of each size. The lengthfrequency distribution was determined for those species with samples or sub-samples presenting more than 500 specimens.

\section{RESULTS}

Between 2012 and 2016, 2,872 tows were carried out, 2,805 of them with Antarctic krill (Euphausia superba) catch. For the bycatch analysis, 611 hauls $(21.8 \%)$ were used, obtaining 784 samples of $25 \mathrm{~kg}$ (total $19,600 \mathrm{~kg}$ ), an equal number of $1 \mathrm{~kg}$ sub-samples (total $784 \mathrm{~kg}$ ) (in some hauls more than one sample was taken). The total catch of krill in the five years was 37,471.10 t (Table $1)$. 


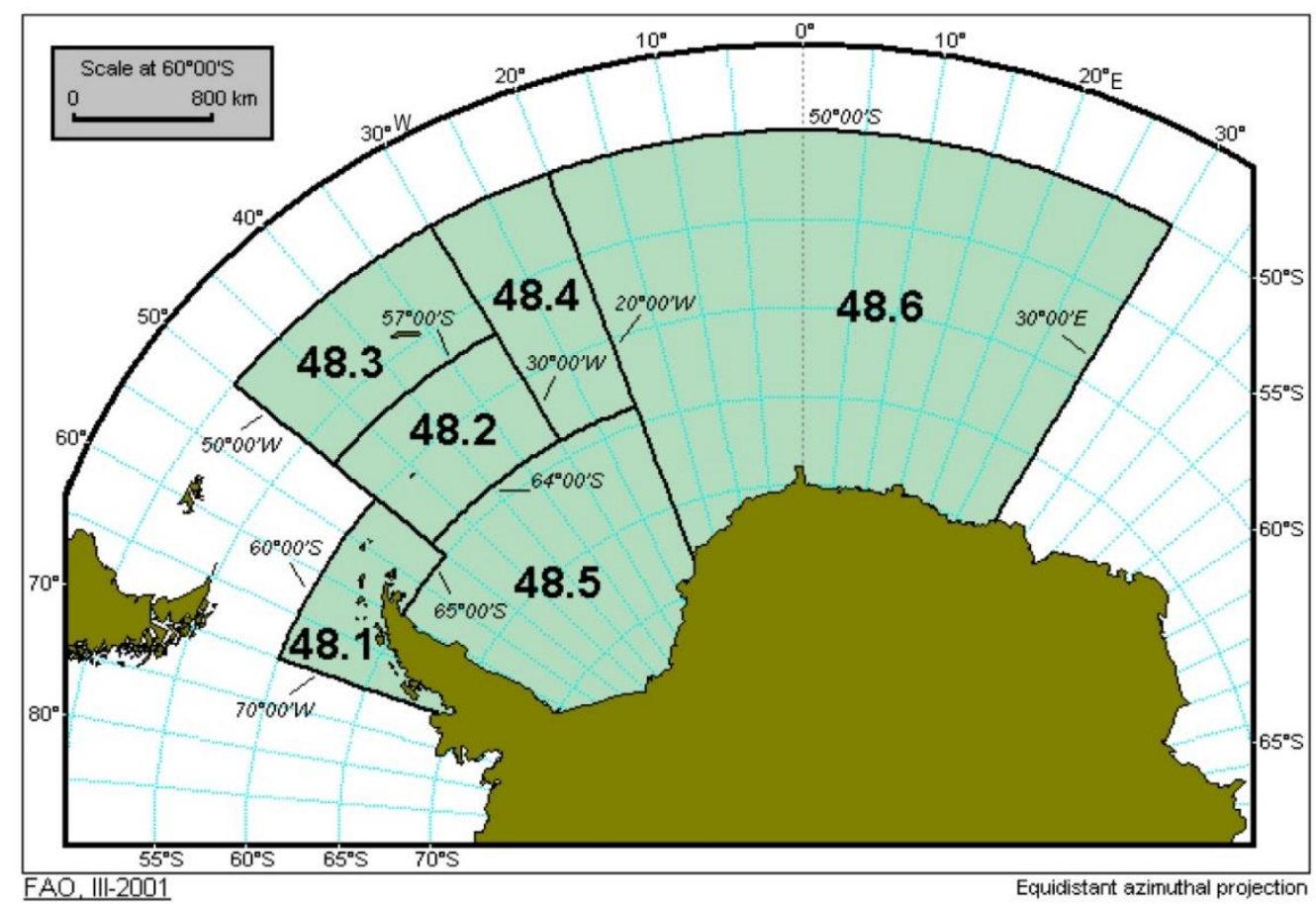

Figure 1. Statistical subareas established by FAO in the South Pacific and Atlantic Oceans. From: FAO Fisheries and Aquaculture Department [online], Rome.

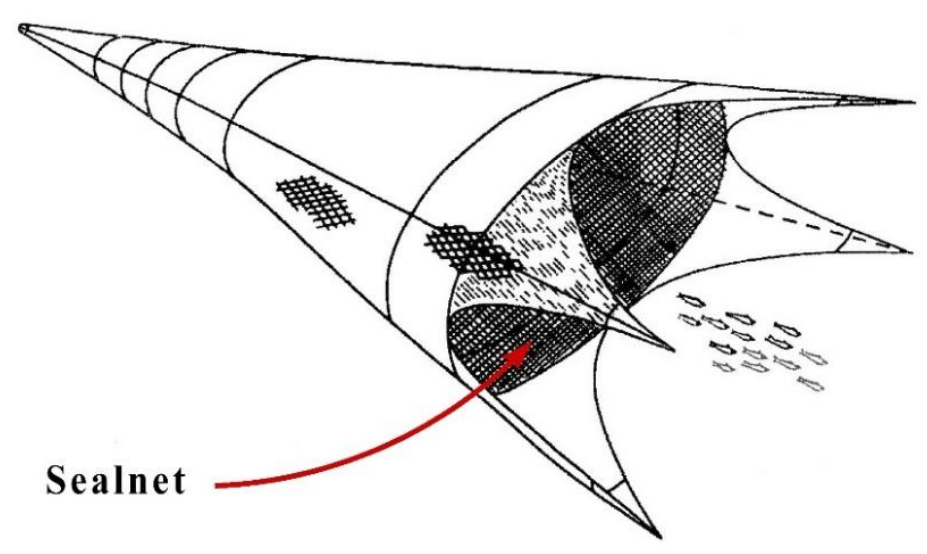

Figure 2. Schematic drawing of a midwater trawl that shows the "Sealnet" used to avoid penguins and marine mammals from entering the Antarctic krill (Euphausia superba) fishing nets.

From the $25 \mathrm{~kg}$ samples, 18 fish species were identified, and three of them could only be determined at the family level. Among the fish, in order of importance regarding the number of specimens present in the samples, were painted notie Lepidonotothen larseni, ocellate icefish Chionodraco rastrospinosus, mackerel icefish Champsocephalus gunnari, and crocodile icefish Chionodraco hamatus. However, the most significant number of specimens identified other than fish were Salpidae and Amphipoda (Table 1). The specimens from the former possibly correspond to
Salpa thompsoni, which is the most common species in Antarctic waters (Panasiuk et al., 2016).

In the overall bycaught by numbers, fish accounted for $12.61 \%$, while other species $87.37 \%$ and unknown species $0.02 \%$. On the contrary, fish contributed $74.50 \%$ in weight, while other species were with $25.49 \%$, and unknown species $0.01 \%$.

A total of 10 fish species were identified in the $1 \mathrm{~kg}$ sub-samples, in addition to specimens that could not be precisely determined; these were grouped as belonging to the Channichthyidae family. On the other hand, the 
Table 1. Incidental catch of marine organisms (in number of individuals and weight) in the $25 \mathrm{~kg}$ samples from Antarctic krill (Euphausia superba) catches, between 2012 and 2016.

\begin{tabular}{|c|c|c|c|c|c|c|c|c|c|c|c|c|c|}
\hline \multirow{3}{*}{ Taxonomic groups } & \multirow{3}{*}{$\begin{array}{l}\text { CCAMLR } \\
\text { code }\end{array}$} & \multicolumn{10}{|c|}{ Year } & \multirow{2}{*}{\multicolumn{2}{|c|}{ Total }} \\
\hline & & \multicolumn{2}{|c|}{2012} & \multicolumn{2}{|c|}{2013} & \multicolumn{2}{|c|}{2014} & \multicolumn{2}{|c|}{2015} & \multicolumn{2}{|c|}{2016} & & \\
\hline & & $\mathrm{n}$ & $\begin{array}{c}\text { Catch } \\
(\mathrm{kg})\end{array}$ & $\mathrm{n}$ & $\begin{array}{c}\text { Catch } \\
(\mathrm{kg})\end{array}$ & $\mathrm{n}$ & $\begin{array}{l}\text { Catch } \\
(\mathrm{kg})\end{array}$ & $\mathrm{n}$ & $\begin{array}{c}\text { Catch } \\
(\mathrm{kg})\end{array}$ & $\mathrm{n}$ & $\begin{array}{l}\text { Catch } \\
(\mathrm{kg})\end{array}$ & $\mathrm{n}$ & $\begin{array}{l}\text { Catch } \\
(\mathrm{kg})\end{array}$ \\
\hline \multicolumn{14}{|l|}{ Pisces } \\
\hline Champsocephalus gunnari & ANI & 226 & 9.440 & 5 & 1.600 & 15 & 0.362 & 4 & 0.268 & & & 250 & 11.670 \\
\hline Chionodraco hamatus & TIC & & & 9 & 0.013 & 83 & 0.165 & 95 & 0.084 & & & 187 & 0.262 \\
\hline $\begin{array}{l}\text { Pseudochaenichthys } \\
\text { georgianus }\end{array}$ & SGI & & & 14 & 6.740 & & & & & & & 14 & 6.740 \\
\hline Pleuragramma antarcticum & ANS & & & 18 & 0.230 & 9 & 0.04 & 4 & 0.004 & 39 & 0.074 & 70 & 0.348 \\
\hline Cryodraco antarcticus & FIC & & & & & 2 & 0.006 & 17 & 0.041 & 16 & 0.035 & 35 & 0.082 \\
\hline Muraenolepis spp. & MRL & & & & & 3 & 0.003 & 2 & 0.004 & & & 5 & 0.007 \\
\hline Lepidonotothen larseni & NOL & & & & & 18 & 0.014 & 550 & 1.004 & 24 & 0.039 & 592 & 1.057 \\
\hline Protomyctophum tenisoni & PRE & & & & & 1 & 0.008 & & & & & 1 & 0.008 \\
\hline Chaenodraco wilsoni & WIC & & & & & 15 & 0.019 & 12 & 0.04 & 9 & 0.033 & 36 & 0.092 \\
\hline Gymnodraco acuticeps & GYA & & & & & & & 1 & 0.001 & & & 1 & 0.001 \\
\hline Chionodraco rastrospinosus & KIF & & & & & & & 40 & 0.054 & 264 & 0.261 & 304 & 0.315 \\
\hline Notolepis spp. & NOE & & & & & & & 7 & 0.003 & 3 & 0.003 & 10 & 0.006 \\
\hline Notothenia rossii & NOR & & & & & & & 1 & 0.006 & & & 1 & 0.006 \\
\hline Dissostichus mawsoni & TOA & & & & & & & 1 & 0.003 & & & 1 & 0.003 \\
\hline Artedidraco spp. & ART & & & & & & & & & 1 & 0.001 & 1 & 0.001 \\
\hline Nototheniidae & NOX & & & & & & & 1 & 0.001 & & & 1 & 0.001 \\
\hline Myctophidae & LXX & & & & & & & 15 & 0.037 & 1 & 0.003 & 16 & 0.04 \\
\hline Channichthyidae & $\mathrm{ICX}$ & & & & & & & 1 & 0.001 & & & 1 & 0.001 \\
\hline \multicolumn{14}{|l|}{ Other taxa } \\
\hline Pandalidae & DCP & & & & & & & 10 & 0.03 & & & 10 & 0.03 \\
\hline Crustacea & FCX & & & & & & & 46 & 0.017 & & & 46 & 0.017 \\
\hline Amphipoda & AQM & & & & & 2 & 0.002 & 3,018 & 0.652 & 1 & 0.004 & 3,021 & 0.658 \\
\hline Medusae & JEL & & & & & & & 4 & 0.005 & & & 4 & 0.005 \\
\hline Salpidae & SPX & & & & & 12 & 0.012 & 5,768 & 3.527 & 1,713 & 2.806 & 7,493 & 6.345 \\
\hline Cephalopoda & CEP & & & & & & & 3 & 0.007 & & & 3 & 0.007 \\
\hline Unknown species & UNK & & & & & & & 2 & 0.002 & & & 2 & 0.002 \\
\hline Total & & 226 & 9.440 & 46 & 8.583 & 160 & 0.631 & 9,602 & 5.791 & 2,071 & 3.259 & 12,105 & 27.704 \\
\hline Total weight of samples $(\mathrm{kg})$ & & \multicolumn{2}{|c|}{5,075} & \multicolumn{2}{|c|}{3,250} & \multicolumn{2}{|c|}{3,175} & \multicolumn{2}{|c|}{6,200} & \multicolumn{2}{|c|}{1,900} & \multicolumn{2}{|c|}{19,600} \\
\hline Samples (n) & & \multicolumn{2}{|c|}{203} & \multicolumn{2}{|c|}{130} & \multicolumn{2}{|c|}{127} & \multicolumn{2}{|c|}{248} & \multicolumn{2}{|c|}{76} & \multicolumn{2}{|c|}{784} \\
\hline $\begin{array}{l}\text { The weight percentage of by } \\
\text { catch in total samples }\end{array}$ & & \multicolumn{2}{|c|}{0.186} & & 264 & & 20 & 0.0 & & 0.1 & & 0.1 & \\
\hline $\begin{array}{l}\text { Individuals (n) per kg of } \\
\text { capture }\end{array}$ & & & .04 & & 01 & & 05 & 1. & & 1. & & 0. & \\
\hline Annual krill catch (tonnes) & & 9,3 & 95.75 & & 35.92 & & 3.66 & 7,27 & 8.61 & 3,70 & 7.12 & 37,47 & 1.10 \\
\hline
\end{tabular}

presence of Amphipoda and Salpidae was established in the other species category. Unlike the results for the $25 \mathrm{~kg}$ samples, in this case, the most abundant species found was mackerel icefish (Table 2).

In this particular case, fish numbers accounted for $84.69 \%$, while the other species made up $15.31 \%$. In contrast, regarding observed weight, fish accounted for $94.91 \%$, while the other species only made up $5.09 \%$.

\section{Length measurements and frequency distributions}

Only mackerel icefish and painted notie were present in enough quantity (>500 individuals) to carry out a representative analysis of their respective lengthfrequency distributions. Mackerel icefish specimens presented values between 2 to $43 \mathrm{~cm}$ TL, with a predominant mode between 5 and $6 \mathrm{~cm}$ TL and a minor mode between 12 and $14 \mathrm{~cm}$ in total length (Fig. 3a). In the case of painted notie, the length ranged between 3 and $24 \mathrm{~cm}$ TL, with the mode centered on individuals of 5 to $6 \mathrm{~cm} \mathrm{TL}$ (Fig. 3b).

Frequency of occurrence of marine organisms (FO) In the $25 \mathrm{~kg}$ samples, the highest FO in the number of fish corresponded to L. larseni (11.22\%), followed by 
Table 2. Incidental catch of marine organisms (in number of individuals and weight) in the $1 \mathrm{~kg}$ sub-samples from Antarctic krill (Euphausia superba) catches between 2012 and 2016.

\begin{tabular}{|c|c|c|c|c|c|c|c|c|c|c|c|c|c|}
\hline \multirow{3}{*}{ Taxonomic groups } & \multirow{3}{*}{$\begin{array}{l}\text { CCAMLR } \\
\text { code }\end{array}$} & \multicolumn{10}{|c|}{ Year } & \multirow{2}{*}{\multicolumn{2}{|c|}{ Total }} \\
\hline & & \multicolumn{2}{|c|}{2012} & \multicolumn{2}{|c|}{2013} & \multicolumn{2}{|c|}{2014} & \multicolumn{2}{|c|}{2015} & \multicolumn{2}{|c|}{2016} & & \\
\hline & & $\mathrm{n}$ & $\begin{array}{c}\text { Catch } \\
(\mathrm{kg})\end{array}$ & $\mathrm{n}$ & $\begin{array}{c}\text { Catch } \\
(\mathrm{kg})\end{array}$ & $\mathrm{n}$ & $\begin{array}{c}\text { Catch } \\
(\mathrm{kg})\end{array}$ & $\mathrm{n}$ & $\begin{array}{c}\text { Catch } \\
(\mathrm{kg})\end{array}$ & $\mathrm{n}$ & $\begin{array}{c}\text { Catch } \\
(\mathrm{kg})\end{array}$ & $\mathrm{n}$ & $\begin{array}{c}\text { Catch } \\
(\mathrm{kg})\end{array}$ \\
\hline Champsocephalus gunnari & ANI & 485 & 0.980 & 20 & 0.042 & & & & & & & 505 & 1.022 \\
\hline Pleuragramma antarcticum & ANS & 1 & 0.002 & 1 & 0.01 & & & & & & & 2 & 0.012 \\
\hline Cryodraco antarcticus & FIC & 2 & 0.009 & & & 2 & 0.004 & & & & & 4 & 0.013 \\
\hline Chionodraco hamatus & TIC & & & & & 1 & 0.001 & & & & & 1 & 0.001 \\
\hline Electrona carlsbergi & ELC & & & 2 & 0.004 & & & & & & & 2 & 0.004 \\
\hline Lepidonotothen kempi & NOK & & & 4 & 0.012 & & & & & & & 4 & 0.012 \\
\hline Notothenia rossii & NOR & & & 1 & 0.008 & & & & & & & 1 & 0.008 \\
\hline Electrona antarctica & ELN & & & & & 2 & 0.012 & 3 & 0.003 & & & 5 & 0.015 \\
\hline Lepidonotothen larseni & NOL & & & & & 1 & 0.002 & & & & & 1 & 0.002 \\
\hline Total & & 493 & 1.019 & 28 & 0.076 & 6 & 0.02 & 3 & 0.041 & 1 & 0.022 & 627 & 1.178 \\
\hline Total weight of sub-samples $(\mathrm{kg})$ & & \multicolumn{2}{|c|}{203} & \multicolumn{2}{|c|}{130} & \multicolumn{2}{|r|}{127} & \multicolumn{2}{|c|}{248} & \multicolumn{2}{|r|}{76} & \multicolumn{2}{|c|}{784} \\
\hline Sub-samples (n) & & \multicolumn{2}{|c|}{203} & \multicolumn{2}{|c|}{130} & \multicolumn{2}{|r|}{127} & \multicolumn{2}{|c|}{248} & \multicolumn{2}{|r|}{76} & \multicolumn{2}{|c|}{784} \\
\hline $\begin{array}{l}\text { Weight percentage of by-catch in } \\
\text { total sub-samples }\end{array}$ & & \multicolumn{2}{|c|}{0.502} & \multicolumn{2}{|c|}{0.058} & \multicolumn{2}{|c|}{0.016} & \multicolumn{2}{|c|}{0.017} & \multicolumn{2}{|c|}{0.029} & \multicolumn{2}{|c|}{0.150} \\
\hline Individuals (n) per (1) $\mathrm{kg}$ of capture & & \multicolumn{2}{|c|}{2.43} & & 22 & & 0.06 & & 31 & & .29 & & 80 \\
\hline Annual krill catch (tonnes) & & & 5.75 & & 85.92 & & 503.66 & & 78.61 & & 07.12 & 37,4 & 1.10 \\
\hline
\end{tabular}
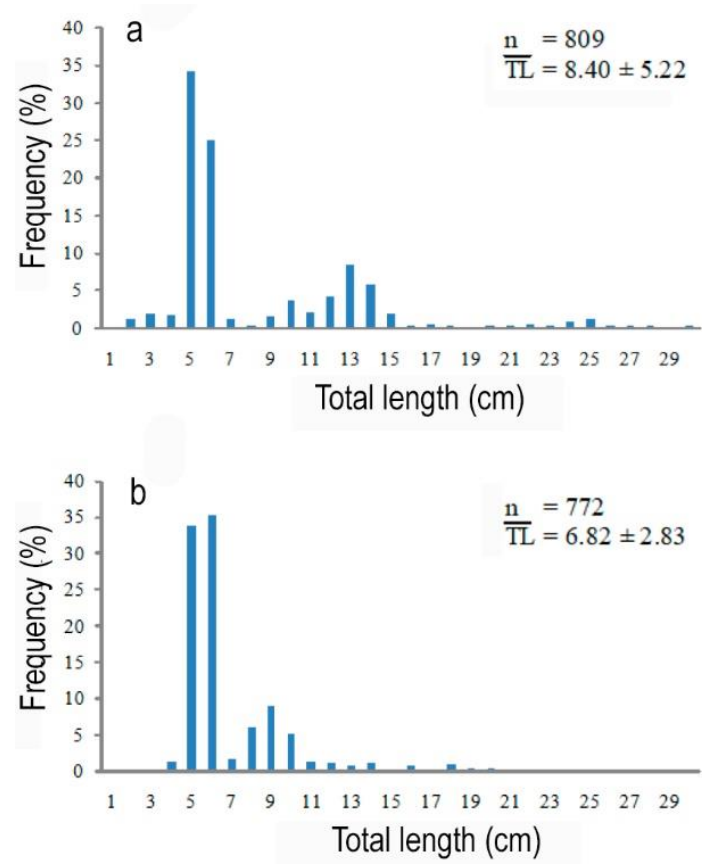

Figure 3. Total length $(\mathrm{cm})$ of fishes bycaught in Antarctic krill Euphausia superba fishing; a) Champsocephalus gunnari, b) Lepidonotothen larseni.
C. hamatus (8.67\%), C. rastrospinosus (8.55\%) and C. gunnari (4.59\%). Concerning other taxa, Salpidae showed a frequency of $29.08 \%$ and Amphipoda $10.20 \%$ (Table 3).

In the $1 \mathrm{~kg}$ sub-samples, the highest FO corresponded to mackerel icefish with $11.22 \%$, while the remaining species presented values below $0.40 \%$. In the case of other species, the Salpidae group recorded an FO of $4.46 \%$, and the Amphipoda group showed a frequency of occurrence of $1.91 \%$ (Table 4 ).

\section{Seabirds and marine mammals}

Seabirds and marine mammals' observation, in the vicinity of the vessel, was made for 791 hauls, corresponding to $28.2 \%$ of the overall fishing effort in hauls with a catch. However, none of the trawlers observed by the Scientific Observer determined the interaction of birds or marine mammals with the ship. The interactions described in this document correspond to those recorded during the trips without indication of how they occurred. A total of 29 interactions with seabirds and marine mammals were recorded between 2012 and 2016. Of this total, 20 corresponded to seabirds and 9 to mammals; the latter explicitly corres- 
Table 3. The frequency of occurrence (\%FO) of marine organisms in the $25 \mathrm{~kg}$ samples (n) from Antarctic krill (Euphausia superba) catches between 2012 and 2016.

\begin{tabular}{|c|c|c|c|c|c|c|c|c|c|c|c|c|c|}
\hline \multirow{3}{*}{ Taxonomic groups } & \multirow{3}{*}{$\begin{array}{l}\text { CCAMLR } \\
\text { code }\end{array}$} & \multicolumn{10}{|c|}{ Year } & \multirow{2}{*}{\multicolumn{2}{|c|}{ Total }} \\
\hline & & \multicolumn{2}{|c|}{2012} & \multicolumn{2}{|c|}{2013} & \multicolumn{2}{|c|}{2014} & \multicolumn{2}{|c|}{2015} & \multicolumn{2}{|c|}{2016} & & \\
\hline & & $\mathrm{n}$ & $\% \mathrm{FO}$ & $\mathrm{n}$ & $\% \mathrm{FO}$ & $\mathrm{n}$ & $\% \mathrm{FO}$ & $\mathrm{n}$ & $\% \mathrm{FO}$ & $\mathrm{n}$ & $\% \mathrm{FO}$ & $\mathrm{n}$ & $\% \mathrm{FO}$ \\
\hline \multicolumn{14}{|l|}{ Pisces } \\
\hline Champsocephalus gunnari & ANI & 22 & 10.84 & 5 & 3.85 & 5 & 3.93 & 4 & 1.61 & & & 36 & 4.59 \\
\hline Chionodraco hamatus & TIC & & & 9 & 6.92 & 36 & 28.35 & 23 & 9.27 & & & 68 & 8.67 \\
\hline Pseudochaenichthys georgianus & SGI & & & 7 & 5.38 & & & & & & & 7 & 0.89 \\
\hline Pleuragramma antarcticum & ANS & & & 15 & 11.54 & 7 & 5.51 & 2 & 0.81 & 6 & 7.89 & 30 & 3.83 \\
\hline Cryodraco antarcticus & FIC & & & & & 2 & 1.57 & 12 & 4.84 & 11 & 14.47 & 25 & 3.19 \\
\hline Muraenolepis spp. & MRL & & & & & 3 & 2.36 & 2 & 0.81 & & & 5 & 0.64 \\
\hline Lepidonotothen larseni & NOL & & & & & 7 & 5.51 & 72 & 29.03 & 9 & 11.84 & 88 & 11.22 \\
\hline Protomyctophum tenisoni & PRE & & & & & 1 & 0.79 & & & & & 1 & 0.13 \\
\hline Chaenodraco wilsoni & WIC & & & & & 13 & 10.24 & 10 & 4.03 & 8 & 10.53 & 31 & 3.95 \\
\hline Gymnodraco acuticeps & GYA & & & & & & & 1 & 0.40 & & & 1 & 0.13 \\
\hline Chionodraco rastrospinosus & KIF & & & & & & & 13 & 5.24 & 54 & 71.05 & 67 & 8.55 \\
\hline Dissostichus mawsoni & TOA & & & & & & & 1 & 0.40 & & & 1 & 0.13 \\
\hline Artedidraco spp. & ART & & & & & & & & & 1 & 1.32 & 1 & 0.13 \\
\hline Notolepis spp. & NOE & & & & & & & 2 & 0.81 & 2 & 2.63 & 4 & 0.51 \\
\hline Notothenia rossii & NOR & & & & & & & 1 & 0.40 & & & 1 & 0.13 \\
\hline Nototheniidae & NOX & & & & & & & 1 & 0.40 & & & 1 & 0.13 \\
\hline Myctophidae & LXX & & & & & & & 11 & 4.44 & 1 & 1.32 & 12 & 1.53 \\
\hline Channichthyidae & ICX & & & & & & & 1 & 0.40 & & & 1 & 0.13 \\
\hline \multicolumn{14}{|l|}{ Other taxa } \\
\hline Amphipoda & $\mathrm{AQM}$ & & & & & 2 & 1.57 & 77 & 31.05 & 1 & 1.32 & 80 & 10.20 \\
\hline Salpidae & SPX & & & & & 9 & 7.09 & 152 & 61.29 & 67 & 88.16 & 228 & 29.08 \\
\hline Cephalopoda & CEP & & & & & & & 3 & 1.21 & & & 3 & 0.38 \\
\hline Crustacea & FCX & & & & & & & 8 & 3.23 & & & 8 & 1.02 \\
\hline Pandalidae & DCP & & & & & & & 8 & 3.23 & & & 8 & 1.02 \\
\hline Medusae & JEL & & & & & & & 3 & 1.21 & & & 3 & 0.38 \\
\hline Unknown species & UNK & & & & & & & 2 & 0.81 & & & 2 & 0.26 \\
\hline Total samples (n) & & & 203 & & 130 & & 127 & & 48 & & 76 & & 84 \\
\hline
\end{tabular}

ponded to the Antarctic fur seals Arctocephalus gazella. Concerning the hauls total, interaction with seabirds was in $2.53 \%$ of the hauls, and with marine mammals in $1.13 \%$.

The seabird species that interacted with the vessel or fishing gear were: six Cape petrel (Daption capense), five Wilson's storm petrel (Oceanites oceanicus), four snow petrel (Pagodroma nivea), three southern fulmar (Fulmarus glacialoides), one gentoo penguin (Pygoscelis рариа), and one Antarctic petrel (Thalassoica antarctica). Of these seabirds, only three specimens were killed; one each of $D$. capense, $O$. oceanicus, and $F$. glacialoides. The remaining 17 individuals were released without apparent damage. Concerning dead individuals, there was a dead seabird for every 264 trawls on the average. Regarding the A. gazella specimens caught by the net, two died. The remaining seven individuals were released without harm down the stern ramp of the ship.

\section{DISCUSSION}

FAO defined bycatch as those species caught during the fishing process of other resources of interest, or specimens of sizes different than those required for the same target resource. It represents the catch fraction that has no interest or economic value for humans, and that is discarded and returned to the sea, often dead, injured, or about to die (http://www.fao.org/fi/glossary/ default.asp). In the fishery for Antarctic krill (Euphausia superba), all species caught, except for krill, are considered as bycatch, consisting mainly of plankton and meroplankton organisms, and to a lesser extent by fish and other taxa.

In recent decades, special attention has been given to the effects that fishing activities may have on species that are not their objective and on the actions that can be taken to avoid or at least prevent or mitigate their capture (Dietrich \& Melvin, 2004). In southern waters, 
Table 4. The frequency of occurrence (\%FO) of marine organisms in the $1 \mathrm{~kg}$ sub-samples (n) from Antarctic krill (Euphausia superba) catches between 2012 and 2016.

\begin{tabular}{|c|c|c|c|c|c|c|c|c|c|c|c|c|c|}
\hline \multirow{3}{*}{ Taxonomic groups } & \multirow{3}{*}{$\begin{array}{l}\text { CCAMLR } \\
\text { code }\end{array}$} & \multicolumn{10}{|c|}{ Year } & \multirow{2}{*}{\multicolumn{2}{|c|}{ Total }} \\
\hline & & \multicolumn{2}{|c|}{2012} & \multicolumn{2}{|c|}{2013} & \multicolumn{2}{|c|}{2014} & \multicolumn{2}{|c|}{2015} & \multicolumn{2}{|c|}{2016} & & \\
\hline & & $\mathrm{n}$ & $\% \mathrm{FO}$ & $\mathrm{n}$ & $\% \mathrm{FO}$ & $\mathrm{n}$ & $\% \mathrm{FO}$ & $\mathrm{n}$ & $\% \mathrm{FO}$ & $\mathrm{n}$ & $\% \mathrm{FO}$ & $\mathrm{n}$ & $\% \mathrm{FO}$ \\
\hline \multicolumn{14}{|l|}{ Pisces } \\
\hline Champsocephalus gunnari & ANI & 81 & 39.90 & 7 & 5.38 & & & & & & & 88 & 11.22 \\
\hline Pleuragramma antarcticum & ANS & 1 & 0.49 & 1 & 0.77 & & & & & & & 2 & 0.26 \\
\hline Cryodraco antarcticus & FIC & 1 & 0.49 & & & 1 & 0.79 & & & & & 2 & 0.26 \\
\hline Pseudochaenichthys georgianus & SGI & 2 & 0.99 & & & & & & & & & 2 & 0.26 \\
\hline Chionodraco hamatus & TIC & & & & & 1 & 0.79 & & & & & 1 & 0.13 \\
\hline Electrona carlsbergi & ELC & & & 1 & 0.77 & & & & & & & 1 & 0.13 \\
\hline Lepidonotothen kempi & NOK & & & 1 & 0.77 & & & & & & & 1 & 0.13 \\
\hline Notothenia rossii & NOR & & & 1 & 0.77 & & & & & & & 1 & 0.13 \\
\hline Electrona antarctica & ELN & & & & & 2 & 1.57 & & & & & 2 & 0.26 \\
\hline Lepidonotothen larseni & NOL & & & & & 1 & 0.79 & 2 & 0.81 & & & 3 & 0.38 \\
\hline Channichthyidae & ICX & & & & & & & & & 1 & 1.32 & 1 & 0.13 \\
\hline \multicolumn{14}{|l|}{ Other taxa } \\
\hline Amphipoda & $\mathrm{AQM}$ & & & & & 1 & 0.79 & 14 & 5.65 & & & 15 & 1.91 \\
\hline Salpidae & SPX & & & & & & & 18 & 7.26 & 17 & 22.37 & 35 & 4.46 \\
\hline Total sub-samples (n) & & \multicolumn{2}{|c|}{203} & \multicolumn{2}{|c|}{130} & \multicolumn{2}{|c|}{127} & \multicolumn{2}{|c|}{248} & \multicolumn{2}{|c|}{76} & \multicolumn{2}{|c|}{784} \\
\hline
\end{tabular}

the main focus has been on studies on the incidental mortality of seabirds and the interaction with marine mammals (e.g., killer whales Orcinus orca, sperm whales Physeter macrocephalus, sealions) produced by longline deep-sea cod (Dissostichus eleginoides) fishing (e.g., González et al., 2012; Suazo et al., 2014; Franco-Trecu et al., 2019). Likewise, these investigations were extended regarding the occurrence of interactions when a trawling gear is used (e.g., Williams \& Capdeville, 1996; Weimerskirch et al., 2000; Roe, 2005; Sullivan et al., 2006). The growing concern about this problem has motivated that both national and international action plans are proposed to mitigate unwanted effects in fishing operations (e.g., Beddington \& De la Mare, 1984; Moreno \& Arata, 2005; Trouwborst, 2008; Kuepfer \& Debski, 2019).

CCAMLR, at its 1992 Meeting, adopted a Scheme of International Scientific Observation as required under Article XXIV of the Convention. In 1993, this Commission published the first version of the Scientific Observers Manual (CCAMLR, 2011), giving rise to the systematic collection of bycatch data, requiring scientific observers on board each ship. For the collection of this data, forms designed for that purpose are used. In parallel, information on non-target catch must be provided by each vessel in CCAMLR Form C1 that describes the operation of ships in fisheries conducted in waters under the scope of this international organization. Likewise, it is important to note that all the management provisions established annually by the CCAMLR are incorporated into Chilean legislation, which applies to the fishing operations carried out by national flag vessels in Antarctic waters. The validity of the records obtained by scientific observers is closely linked to the training they received in each country, whether they are national or international observers, and in having appropriate taxonomic keys for the identification of the specimens that constitute bycatch (i.e., Iwami \& Naganobu, 2007). However, there is consensus regarding an increase in the data quality from the observer scheme during the last years, as well as an increase in the fish bycatch reported in the commercial krill catch data (CCAMLR, 2016). Substantial improvement will be achieved in the future by the use of genetic identification of fish caught as bycatch in the Antarctic krill fishery (Polanowski et al., 2018).

The incidental catch of these organisms is of concern regarding the effect produced directly in each population, and the consequences produced in the Antarctic ecosystem at a global level. Motivates the need for further research to define which species are 
affected and to what extent, to propose appropriate methods or mechanisms for the prevention or reduction of this cryptic impact. Additionally, obtaining bycatch indices (e.g., number of fish per ton of krill, $\mathrm{kg}$ of fish per hour or kilograms of fish per ton of krill) allows estimating the magnitude of losses that would occur for each species in the entire krill fishery. It also provides the potential to evaluate the possible impact of the krill fishery on the population of krill-eating fish species, either directly through bycatch or through ecosystem interactions (CCAMLR, 2016).

Another aspect of interest to know is the interaction of seabirds and marine mammals with this fishery. In the case of flying birds, injuries or death occurred mainly due to collisions with the net-sonde cable (Weimerskirch et al., 2000), or when flying birds, and sometimes penguins, try to take specimens caught in the net. It happens especially when the nets are being hauled onto the ship at the end of the trawl operation.

Interactions with marine mammals occurred when these attend vessels, to feed on fish that escape from the net. In general, measures aimed at preventing mammals (e.g., sea lions or seals) from entering the trawl net are based on the use of physical barriers to prevent them from entering the net or by using devices or openings that allow their escape (Hooper et al., 2005). The use of seal-net in the mouth of the net is preferred to prevent animals from entanglement in the fishing gear meshes (e.g., wings or square), or prevent the entry of organisms larger than krill into the nets.

According to the information collected during the 2012-2016 period, interactions with seabirds and marine mammals were scarce, and the majority of the interactions resulted in unharmed animals (Table 5). The Conservation Measures adopted by CCAMLR to minimize bycatch of seabirds and marine mammals in the trawl fishery, in The Convention Area of this organization, mainly includes a) the prohibition of the use of net monitor cables on vessels in the CAMLR Convention Area; b) nets shall be cleaned before shooting to remove items that might attract birds; c) the waste discharge (whole fish or other organisms) and fish remains during the setting and hauling of the trawl is prohibited, and d) recommendation for the boat to work with the least possible lighting in dark hours (CCAMLR Conservation Measure 25-03). Besides, in the particular case of the krill fishery, the use of mammalian exclusion devices is mandatory (CCAMLR Conservation Measure 21-03).

Interannual variability in the results obtained is reflected in the different sources of information that CCAMLR permanently collects (CCAMLR, 2018). In this sense, Watters (1996) provided a synthesis from various studies of juvenile fish bycatch in krill trawls in different subareas and divisions of the Antarctic region between 1982 and 1995. The same author showed the variability in the species cataloged as the most abundant, indicating that in Subarea 48, the fish more commonly bycaught were Electrona antarctica, Champsocephalus gunnari, Lepidonotothen larseni, Chaenocephalus aceratus, and Chionobathyscus dewitti.

On this occasion, results obtained showed that in weight, both in samples and sub-samples, the leading bycatch group corresponds to fishes $(74.5 \%$ in the 25 $\mathrm{kg}$ samples and $94.9 \%$ in the $1 \mathrm{~kg}$ sub-samples). Mackerel icefish (C. gunnari) being the predominant species, followed by the South Georgia icefish Pseudochaenichthys georgianus and painted notie $L$. larseni. A similar result is also highlighted by CCAMLR (2016), where C. gunnari and L. larseni contributed the majority of the bycatch biomass.

However, when considering the number of specimens retained by the nets, this predominance is displayed by the other taxa, especially in the $1 \mathrm{~kg}$ subsamples, which represented $87.4 \%$. On the other hand, Salpidae and Amphipoda exceptional amount registered during 2016 its origin is out of the scope of this study.

The presence of demersal fish in krill fisheries might be associated with vertical migrations in the water column to feed on krill (e.g., C. gunnari). Other causes may be related to fishing hauls conducted in shallow waters, e.g., in the Bransfield Strait and the vicinity of the South Shetland Islands. In this same sense, Everson et al. (1991), Pankratov \& Pakhomov (1992), and Pakhomov \& Pankratov (1994) emphasized that the magnitude of juvenile fish bycatch would be lower in krill fishing in high seas. Also, the presence of Myctophidae in 2015 and 2016 (Table 1) could be associated with hauls carried out in waters of greater depth than usual (Everson et al., 1991).

When considering the length-frequency distributions for C. gunnari and L. larseni, size differences can be observed between the 25 and $1 \mathrm{~kg}$ sub-samples. In the former, the majority of specimens measured $>8 \mathrm{~cm}$ $\mathrm{TL}$ and in the sub-sample specimens were small in length (Fig. 3), explained by the methodology adopted by CCAMLR in the sampling protocol, where only the presence of larger fish is quantified in the $25 \mathrm{~kg}$ samples. In contrast, the smaller specimens are determined in the $1 \mathrm{~kg}$ sub-samples. At the same time, the most relevant modes in both $C$. gunnari and $L$. larseni (4-6 cm TL) would correspond to individuals in their first year of life. The fish sizes in the modes mentioned above coincide with the results presented previously in CCAMLR (2016). 
Table 5. Ship and fishing gear interactions with birds and marine mammals during the Antarctic krill (Euphausia superba) fishing operations between 2012 and 2016.

\begin{tabular}{|c|c|c|c|c|c|c|c|c|c|}
\hline \multirow{2}{*}{ Species } & & \multirow{2}{*}{$\begin{array}{l}\text { CCAMLR } \\
\text { code }\end{array}$} & \multirow{2}{*}{ Condition } & \multicolumn{5}{|c|}{ Year } & \multirow{2}{*}{ Total } \\
\hline & & & & 2012 & 2013 & 2014 & 2015 & 2016 & \\
\hline \multirow{18}{*}{ Birds } & \multirow{3}{*}{ Daption capense } & \multirow{3}{*}{ DAC } & Dead & & 1 & & & & 1 \\
\hline & & & Injured & & & & & & 0 \\
\hline & & & Alive & & & & 2 & 3 & 5 \\
\hline & \multirow{3}{*}{ Oceanites oceanicus } & \multirow{3}{*}{ OCO } & Dead & & & & 1 & & 1 \\
\hline & & & Injured & & & & & & 0 \\
\hline & & & Alive & & & & 4 & & 4 \\
\hline & \multirow{3}{*}{ Pygoscelis papua } & \multirow{3}{*}{ PYP } & Dead & & & & & & 0 \\
\hline & & & Injured & & & & & & 0 \\
\hline & & & Alive & & & & 1 & & 1 \\
\hline & \multirow{3}{*}{ Fulmarus glacialoides } & \multirow{3}{*}{ FUG } & Dead & & & & 1 & & 1 \\
\hline & & & Injured & & & & & & 0 \\
\hline & & & Alive & & & & 2 & & 2 \\
\hline & \multirow{3}{*}{ Pagodroma nivea } & \multirow{3}{*}{ PWP } & Dead & & & & & & 0 \\
\hline & & & Injured & & & & & & 0 \\
\hline & & & Alive & & & & 3 & 1 & 4 \\
\hline & \multirow{3}{*}{ Thalassoica antárctica } & \multirow{3}{*}{ TAA } & Dead & & & & & & 0 \\
\hline & & & Injured & & & & & & 0 \\
\hline & & & Alive & & & & & 1 & 1 \\
\hline \multirow{3}{*}{ Mammals } & \multirow{3}{*}{ Arctocephalus gazella } & \multirow{3}{*}{ SEA } & Dead & & & 1 & 1 & & 2 \\
\hline & & & Injured & & & & & & 0 \\
\hline & & & Alive & & 2 & & 5 & & 7 \\
\hline
\end{tabular}

Of all the species determined as bycatch, the mackerel icefish is the only species that is commercially caught around South Georgia Island in the South Atlantic. In contrast, in other Antarctic areas, this species has only been an investigation subject through fishing operations with mid-water trawls (Arana et al., 2016, 2018) and bottom trawls (e.g., Jones et al., 1999, 2001, 2003; Kock et al., 2002, 2007), respectively. In this study, only $11.22 \%$ of the subsamples of $1 \mathrm{~kg}$ were captured individuals of $C$. gunnari (Table 4). According to estimates made by CCAMLR, a total annual mass of fish bycatch of $370 \mathrm{t}$ was determined in the krill fishery catch of 300,000 t that were made that year, which comprises $40 \%$ mackerel icefish (C. gunnari) and $30 \%$ L. larseni (CCAMLR, 2017). Estimates such as those indicated here contribute to determine the total finfish bycatch of the krill fishery Area 48, and quantify the impact of this bycatch on these fish stocks (Martin et al., 2012).

Finally, we must emphasize the relevance of acquiring information on the bycatch of fish and other taxa, as well as regarding the interactions that occur with birds and marine mammals in the krill fishery. This information represents an important input for the CCAMLR Scientific Committee, the body responsible for proposing conservation measures in Antarctic waters. The availability of these records helps to assess the effects on the resources involved in these fishing operations, as well as on the krill-eating species population and general ecosystem interactions.

\section{ACKNOWLEDGMENTS}

The authors thank the executives of the companies Antarctic Sea Fisheries S.A. and Pesca Chile S.A. for the facilities granted to dispose of the information used in this document. In particular, we recognize the work carried out by the National Scientific Observers, who made the collection of the information on board the FV Betanzos.

\section{REFERENCES}

Arana, P.M., Plaza, G., Arata, J., Alegría, N. \& Viquerat, S. 2016. Finfish distribution and abundance in Subareas 48.1 and 48.2, years 2016-2018. CCAMLR, WG-SAM-16/19: 29 pp.

Arana, P.M., Jones, C.D. \& Alegría, N. 2018. Demersal finfish distribution, abundance, and their biological characteristics in Statistical Subareas 48.1 (northern area) and 48.2 (2018-2020) - cruise report. CCAMLR, SAM-18/25: 54 pp.

Arana, P.M., Rolleri, R. \& De Caso, A. 2020. Chilean Antarctic krill fishery (2011-2016). Latin American 
Journal of Aquatic Research, 48(2): 179-196. doi: 10.3856/vol48-issue2-fulltext-2408

Beddington, J.R. \& De la Mare, W.K. 1984. Interacciones de la captura de mamíferos marinos: confección de modelos y el Océano Austral (contribución de IUCN). SC-CAMLR-III/BG/7: 21 pp.

Commission for the Conservation of Antarctic Marine Living Resources (CCAMLR). 1996. Fish the sea, not the sky. How to avoid bycatch of seabirds when fishing with bottom longlines. CCAMLR, Hobart, 46 pp.

Commission for the Conservation of Antarctic Marine Living Resources (CCAMLR). 2011. Scientific Observers Manual (observation guidelines and reference materials). CCAMLR, Hobart, 71 pp.

Commission for the Conservation of Antarctic Marine Living Resources (CCAMLR). 2013. Fish identification guide for observers in CCAMLR krill fisheries. CCAMLR, WG-EMM-13/07: 6 pp.

Commission for the Conservation of Antarctic Marine Living Resources (CCAMLR). 2014. Update on the analysis of fish bycatch in the krill fishery using data from the CCAMLR Scheme of Scientific Observation. CCAMLR Secretariat, $29 \mathrm{pp}$.

Commission for the Conservation of Antarctic Marine Living Resources (CCAMLR). 2016. Fish bycatch in the krill fishery: 2016 update. CCAMLR Secretary, 28 pp.

Commission for the Conservation of Antarctic Marine Living Resources (CCAMLR). 2017. Krill fishery report 2017. CCAMLR Secretary, $34 \mathrm{pp}$.

Commission for the Conservation of Antarctic Marine Living Resources (CCAMLR). 2018. Krill fishery report 2018. CCAMLR Secretary, $31 \mathrm{pp.}$

Davis, M., Clark, J.M. \& Peatman, T. 2009. A descriptive review of the trawl systems used in the Antarctic krill fishery. CCAMLR, TASO-09/5: $14 \mathrm{pp}$.

Delegation of Chile. 2015. Net diagrams for Chilean vessels notified for krill fishery in 2015/16. Notification ID 86795, 86796, and 86797. CCAMLR, WGEMM-15/03: 5 pp.

Dietrich, K. \& Melvin, E. 2004. Annotated bibliography: seabird interactions with trawl fishing, operations, and cooperative research. Sea Grant Program, WSG-TA 04-02: 4 pp.

Dongwon, L. 2015. Species identification illustrated guide of the Southern Ocean - CCAMLR Convention Area 48, 58, and 88. CCAMLR, WG-EMM-15/06: 80 pp.

Everson, I., Neyelov, A. \& Permitin, Y.E. 1991. Bycatch of fish in the krill fishery. In: Selected Scientific Papers, 1991 (SC-CAMLR-SSPI8). CCAMLR, Hobart, pp. 381-401.
Fischer, W. \& Hureau, J.C. (Eds.). 1985. FAO species identification sheets for fishery purposes. Southern Ocean (fishing Areas 48, 58, and 88) (CCAMLR Convention Area). FAO, Rome.

Franco-Trecu, V., Szephegyi, M.N., Doño, F., Forselledo, R., Reyes, F., Passadore, C., Crespo, E.A. \& Inchausti, P. 2019. Marine mammal bycatch by the industrial bottom trawl fishery at the Río de la Plata Estuary and the adjacent Atlantic Ocean. Latin American Journal of Aquatic Research, 47(1): 89-101.

González, A., Vega, R., Barbieri, M.A. \& Yáñez, E. 2012. Determinación de los factores que inciden en la captura incidental de aves marinas en la flota palangrera pelágica chilena. Latin American Journal of Aquatic Research, 40(3): 786-799.

Hooper, J., Clark, J.M., Charman, C. \& Agnew, D. 2005. Seal mitigation measures on trawl vessels fishing for krill in CCAMLR Subarea 48.3. CCAMLR Science, 12: 195-205.

Iwami, T. 1995. Fishes incidentally caught by Japanese Antarctic krill commercial fishery to the north of the South Shetland Islands during the 1994/95 austral summer. CCAMLR, WG-EMM-95/56: 6 pp.

Iwami, T. \& Naganobu, M. 2007. A guide to the identification of fishes caught along with the Antarctic krill. CCAMLR, WG-EMM-07/32: 27 pp.

Jones, C.D., Kock, K.-H., Ashford, J., DeVries, A., Detrich, K., Hanchet, S., Near, T., Turk, T. \& Wilhelms, S. 2003. Standing stock, biology, diet, and spatial distribution of demersal finfish from the 2003 US AMLR bottom trawl survey of the South Shetland Islands (Subarea 48.1). CCAMLR, WG-FSA-03/38: $31 \mathrm{pp}$.

Jones, C.D., Kock, K.-H., Ramm, D., Ashford, J., Wilhelms, S., Near, T., Gong, N. \& Flores, H. 2001. Results and standing stock biomass estimates of finfish from the 2001 U.S. AMLR bottom trawl survey of the South Shetland Islands (Subarea 48.1). CCAMLR, WG-FSA-01/33 Review, 1: 44 pp.

Jones, C.D., Kock, K.-H., Wilhelms, S., Popp, J., Ramm, D., Dietrich, K., Kappes, P. \& Lombard, D. 1999. Bottom trawl survey of the South Orkney Islands In: Martin, J. (Ed.). AMLR 1998/99 Field season report. South Fisheries Science Center, LJ-99-10: 137-154.

Kock, K.-H., Appel, J., Busch, M., Klimpel, S., Holst, M., Pietschok, D., Pshenichnov, L.V., Riehl, R. \& Schöling, S. 2007. Composition and standing stock estimates of finfish from the 'Polarstern' bottom trawl survey around Elephant Island and the South Shetland Islands (Subarea 48.1), 19 December 2006 - 3 January 2007. CCAMLR, WG-FSA-07/22: 32 pp.

Kock, K.-H., Jones, C.D., Appel, J., Bertouch, G.V., La Mesa, D.F., Pshenichnov, L., Riehl, R., Romeo, T., 
Schöling, S. \& Zane, L. 2002. Standing stock estimates of finfish biomass from the 2002 'Polarstern' bottom trawl survey around Elephant Island and the South Shetland Island with some notes on the composition of catches taken north of Joinville Island - D'Urville Island. CCAMLR, WG-FSA-02/24: 42 pp.

Kuepfer, A. \& Debski, I. 2019. Updates to the ACAP review and best practice advice for reducing the impact of pelagic and demersal trawl fisheries on seabirds. Ninth Meeting of the Seabird Bycatch Working Group, Florianópolis, Brazil, 6-8 May 2019, SBWG9 Document 08: $31 \mathrm{pp}$.

Martin, S.M., Peatman, T., Moir-Clark, J., Godø, O.R. \& Wakeford, R.C. 2012. Analysis of variables influencing finfish bycatch in the krill fishery in Area 48. CCAMLR, WG-EMM-12/28: 25 pp.

Moreno, C.A. \& Arata, J. 2005. Diseño del plan de acción para mitigar efectos de la pesca de palangre sobre aves marinas. Final Report, Project FIP 2003-21: 64 pp.

Onley, D. \& Bartle, S. 1999. Identification of seabirds of the Southern Ocean. A guide for scientific observers aboard fishing vessels. CCAMLR \& Te Papa Press, Wellington.

Pakhomov, E.A. \& Pankratov, S.A. 1994. Bycatch, growth, and feeding of Antarctic juvenile fish taken in krill (Euphausia superba Dana) fisheries in the South Georgia area, in 1992. CCAMLR Science, 1: 129-142.

Panasiuk, A., Słomska, A., Wawrzynek, J., Konik, M. \& Weydmann, A. 2016. Multiyear changes in distribution and abundance of Salpa thompsoni in the western Antarctic Peninsula region. CCAMLR, WGEMM-16/75: 12 pp.

Pankratov, C.A. \& Pakhomov, E.A. 1992. On the problem of bycatch of juvenile fish in krill fishery. CCAMLR, WG-FSA-92/10: 34 pp.

Polanowski, A., Clark, J., Maschette, D., Welsford, D. \& Deagle, B. 2018. Genetic identification of fish caught as bycatch in the Antarctic krill fishery and comparison with observer records. CCAMLR, WGEMM-18/30: 14 pp.

Received: 24 September 2019; Accepted: 17 February 2020
Roe, J.O. 2005. Mitigation trials and recommendations to reduce seabird mortality in the pelagic icefish (Champsocephalus gunnari) fishery (Subarea 48.3). CCAMLR, WG-FSA-05/59: 18 pp.

Sielfeld, W. 1983. Mamíferos marinos de Chile. Ediciones Universidad de Chile, Santiago.

Suazo, C.G., Cabezas, L.A., Moreno, C.A., Arata, J.A., Luna-Jorquera, G., Simeone, A., Adasme, L., Azócar, J., García, M., Yates, O. \& Robertson, G. 2014. Seabird bycatch in Chile: a synthesis of its impacts, and a review of strategies to contribute to the reduction of a global phenomenon. Pacific Seabirds, 41 (1-2): 12 pp.

Sullivan, B.J., Brickle, P., Reid, T.A., Bone, D.G. \& Middleton, D.A.J. 2006. Mitigation of seabird mortality on factory trawlers: trials of three devices to reduce warp cable strikes. Polar Biology, 29: 745-753.

Trouwborst, A. 2008. Seabird bycatch-deathbed conservation or a precautionary and holistic approach? Journal of International Wildlife Law \& Policy, 11: 293-333.

Watters, G. 1996. Bycatch of fishes captured by the krill fishing vessel Chiyo Maru No. 2 in Statistical Area 58 (January to March 1995). CCAMLR Science, 3: 111123.

Weimerskirch, H., Capdeville, D. \& Duhamel, G. 2000. Factors affecting the number and mortality of seabirds attending trawlers and long-liners in the Kerguelen area. Polar Biology, 23: 236-249.

Williams, R. \& Capdeville, D. 1996. Seabird interactions with trawl and longline fisheries for Dissostichus eleginoides and Champsocephalus gunnari. CCAMLR Science, 3: 93-99. 